\title{
LUT
}

University

Elderly Care and Digital Services: Toward a Sustainable Sociotechnical Transition

Pekkarinen Satu, Melkas Helinä, Hyypiä Mirva

This is a Final draft version of a publication

published by Springer

in Human-Centered Digitalization and Services

DOI: 10.1007/978-981-13-7725-9_14

Copyright of the original publication: (c) Springer Nature

Please cite the publication as follows:

Pekkarinen, S., Melkas, H., Hyypiä, M. (2019). Elderly Care and Digital Services: Toward a Sustainable Sociotechnical Transition. In: Toivonen, M., Saari, E. (eds) Human-Centered Digitalization and Services. Translational Systems Sciences, vol 19. Springer, Singapore. pp. 259-284. DOI: 10.1007/978-981-13-7725-9_14

This is a parallel published version of an original publication. This version can differ from the original published article. 


\title{
Chapter 14
}

\section{Elderly care and digital services: Toward a sustainable sociotechnical transition}

\author{
Satu Pekkarinen ${ }^{1}$, Helinä Melkas² and Mirva Hyypiä ${ }^{3}$
}

\begin{abstract}
The elderly care system's sustainability is one of the largest societal challenges of our time. Digitalization and the implementation of technologies in elderly care are viewed as offering possible solutions to the social and economic challenges of sustainability. This study's objective is to examine the development, implementation and diffusion of technologies in elderly care from a sociotechnical perspective, leaning on the concepts of sociotechnical transitions. The focus mainly is on sustainable niche development, including interactions between niches and regimes in terms of sustainable sociotechnical transitions, how niches are developed in relation to sustainability and in which conditions and circumstances promising niches can contribute to regime change in elderly care. Through a multiple-case study in different living environments of elderly residents in Finland, we identify factors that facilitate or hinder sustainable development and the implementation and diffusion of technologies in elderly care. The three case studies concern various types of development: introduction of tablet computers in senior housing, construction of a multi-sensory room in a care home, and the use of a care robot in care homes and in a rehabilitation hospital. Critical factors for sustainable niche development include involving users in the development processes, as well as simultaneous development of technologies and services. The multi-faceted and effective use of technologies requires time and resources. Critical factors in nicheregime interaction are, for example, factors relating to attitudes, as well as technologies' maturity. The need to consider a wider perspective, rather than a singular disruption, is key.
\end{abstract}

Key words: Elderly care system, sustainability, digitalization, sociotechnical transition, Finland, multiplecase study

\section{Introduction}

This chapter considers the sociotechnical transition of elderly care services in Finland, focusing on elderly residents' living environments. Elderly care, as with other fields in society, has been affected strongly by digitalization and various technical devices and systems, such as information systems, e-services, service

\footnotetext{
${ }^{1}$ Satu Pekkarinen,

Lappeenranta-Lahti University of Technology LUT

satu.pekkarinen@1ut.fi

${ }^{2}$ Helinä Melkas

Lappeenranta-Lahti University of Technology LUT

helina.melkas@lut.fi

${ }^{3}$ Mirva Hyypiä,

Lappeenranta-Lahti University of Technology LUT

mirva.hyypia@lut.fi
} 
robots and other technologies that assist physical and mental well-being (e.g., Östlund, 2017; Siegel \& Dorner, 2017; Pekkarinen \& Melkas, 2017). Caring for an ageing population, which includes ensuring the elderly care system's sustainability - particularly sustainability's social and economic pillars — is one of the greatest societal challenges of our time. One possible solution is to use different technologies, but implementing them entails a range of challenges, including a lack of suitable technologies and immature existing ones. Adherence to rigid current practices and past development paths also make the prospect of such changes problematic (Compagna \& Kohlbacher, 2017).

We examine the implementation and use of existing technologies from a sociotechnical perspective, leaning on the multi-level perspective on transitions (MLP) (e.g., Geels, 2002, 2004, 2005, 2011; Geels \& Schot, 2007; Geels \& Kemp, 2007). In this frame, broader landscape changes, such as ageing of population, are perceived to interact dynamically with regimes, such as the present service system and emerging niche technologies and practices (e.g., Geels \& Kemp, 2007; Geels, 2011; Pekkarinen \& Melkas, 2018). Our focus mainly is on sustainable niche development, as well as the interaction between niches and regimes in terms of sustainable sociotechnical transitions. We ask how niches are developed in relation to sustainability, and we ask under what conditions and circumstances promising niches can contribute to regime change. For example, we ask about the facilitators and barriers of change in elderly care. With the help of three case studies, we identify factors that facilitate or hinder sustainable development, implementation and diffusion of technologies in elderly care. The study contributes to research on sustainable transitions and their complex dynamics as reflected in elderly care.

\section{Sustainability of elderly care and the role technology can play}

The sustainable provision of elderly care, mainly in relation to its quality and affordability, is a topic of debate in most welfare states (Essink, 2012). The challenges of providing sustainable care with an ageing population and a shrinking workforce often are presented as being among the 'wicked problems' of our time. Wicked problems are complex policy problems marked by uncertainty and a high interdependency among variables affecting them, as well as difficulty defining them in the first place (Rittel \& Webber, 1973; Bianchi, 2015). Wicked problems cannot be solved within the boundaries of a single organization or specific administrative level, but are characterized by dynamic complexity involving multi-level, multiactor and multi-sectoral challenges (Bianchi, 2015). In the case of societal ageing, this complexity is caused by diverging stakeholder views; uncertain future developments, such as increased life expectancy; and systemic complexity arising from the interplay among feedback mechanisms, accumulations and delays within the system (Auping et al., 2015), e.g., how effective health care affects healthcare costs through increased life expectancy.

The concept of sustainability often is characterized as having three aspects: environmental, economic and social (Littig \& Griessler, 2005; Boström, 2012) - with a cultural pillar sometimes included (Hawkes, 2001). In this paper, our focus mainly is on sustainability's social and economic dimensions. Social sustainability is related to basic needs, e.g., happiness, safety, freedom, dignity, social responsibility, community development and human rights (Vavik \& Keitsch, 2010). Under sustainable development, welfare is a right, not only for current citizens, but also for future generations (Ródenas \& Garcés, 2017). In the context of health care and elderly care, sustainability is related to affordability, accessibility, acceptability and quality (Toebes, 1999; Grin \& Broerse, 2017), as well as system adaptability (Fineberg, 2012). 
The concern about sustainability in elderly care arises from the increasing numbers of people in need of care services and, simultaneously, high turnover in the nursing and support-staff ranks of elderly-care services (Friedland, 2004). A special concern expressed in the public debate - and part of the challenge's wickedness - has been how we can create sustainable systems to care for the ageing population in a way that achieves a balance between the economic and social requirements for sustainability without overemphasizing economic objectives. While the 'Nordic welfare state' has its own distinct history (e.g., Melkas \& Anker, 1998), it faces the same debate, and ongoing initiatives and practical developments include attempts to seek solutions to the complex issues at hand.

In this study, the sustainability of elderly care is considered from the perspective of the implementation of technologies, as technology is expected to play an increasing role in meeting the anticipated sustainability gap in elderly-care services (e.g., Kapadia, Ariani, Li \& Ray, 2015; Malanowski, 2008; Peine, Faulkner, Jæger \& Moors, 2015). However, the expectations for technology often are overemphasized. For instance, Neven (2015) and Peine et al. (2015) noted that gerontechnological innovations (those developed specifically for older people) often are embedded in a 'triple-win narrative', in which policy makers, technology developers and older citizens are said to benefit equally from scientific and technological innovations. Science, technology and innovation are perceived widely to provide the means for solving the 'grand challenge of demographic ageing' (Peine et al., 2015). However, users' involvement in the development of technologies is crucial here. If older technology users are given only a stereotypical identity as passive recipients and not viewed as active agents, it risks a triple loss instead of a triple gain: Older people do not get the technologies they need, companies fail to tap into the business opportunities derived from the ageing population and government subsidies for gerontechnological innovations result in prototypes and experiments that do not proliferate in society and become common (see also Peine et al., 2015).

\section{$3 \quad$ Elderly care in terms of sociotechnical transition}

In this chapter, the changes in elderly care and the role of technology in those changes are tackled in terms of sociotechnical transitions (Geels, 2002; Geels \& Schot, 2007; see also Pekkarinen \& Melkas, 2018). Wicked problems, including ageing of population and its consequences for care services, typically cannot be tackled within one policy sector (Auping et al., 2015) or resolved with help from individual innovations. Instead, the solution involves systemic change, in which social and technical issues co-evolve.

Socio-technical transitions differ from technological transitions in that they include changes in user practices and institutional (e.g., regulatory and cultural) structures, in addition to the technological dimension (Markand, Raven \& Truffen, 2012). However, transition research mainly has focused on 'material' sectors, such as transportation and housing (Ulli-Beer, 2013; Kemp, Schot \& Hoogma, 1998), as well as health care in a few studies (e.g., Kivisaari \& Saranummi, 2008; Kivisaari et al., 2009; Grin \& Broerse [Eds.], 2017). Our objective is to analyse how it can be applied to elderly care (e.g., Bugge et al. 2017).

The concept of sociotechnical transition stresses the interdependence of technological, social, cultural and political dimensions, as well as the mutual adjustment of these dimensions (Smith, Voss \& Grin, 2010; Bugge et al., 2017). The introduction of technologies into society and the development of technological 
innovations require a deep transition that entails the simultaneous development (co-evolution) of technologies, service operations and people's practices and mindsets (e.g., Geels, 2002, 2005; Truffer \& Coenen, 2012). The ageing of the population and economic pressures in the public sector are among the macro-level changes that have contributed to the destabilization of the old 'welfare state regime', acting as triggers for new innovative technologies and practices (Pekkarinen, 2011; Bugge et al., 2015; Pekkarinen \& Melkas, 2018). In addition to digitalization and technological developments, they need to be viewed as co-contributors to the socio-technical tran sition related to elderly care.

The multi-level perspective on transitions (e.g., Geels, 2002, 2004, 2005, 2011; Geels \& Schot, 2007; Geels \& Kemp, 2007) is a concept that tackles changes in the aforementioned way, viewing transitions as co-evolutionary processes occurring at three interrelated conceptual levels: the sociotechnical landscape, sociotechnical regime and bottom-level niche innovations. In this framework, system changes occur through these levels' interplay, as illustrated in Figure 1.

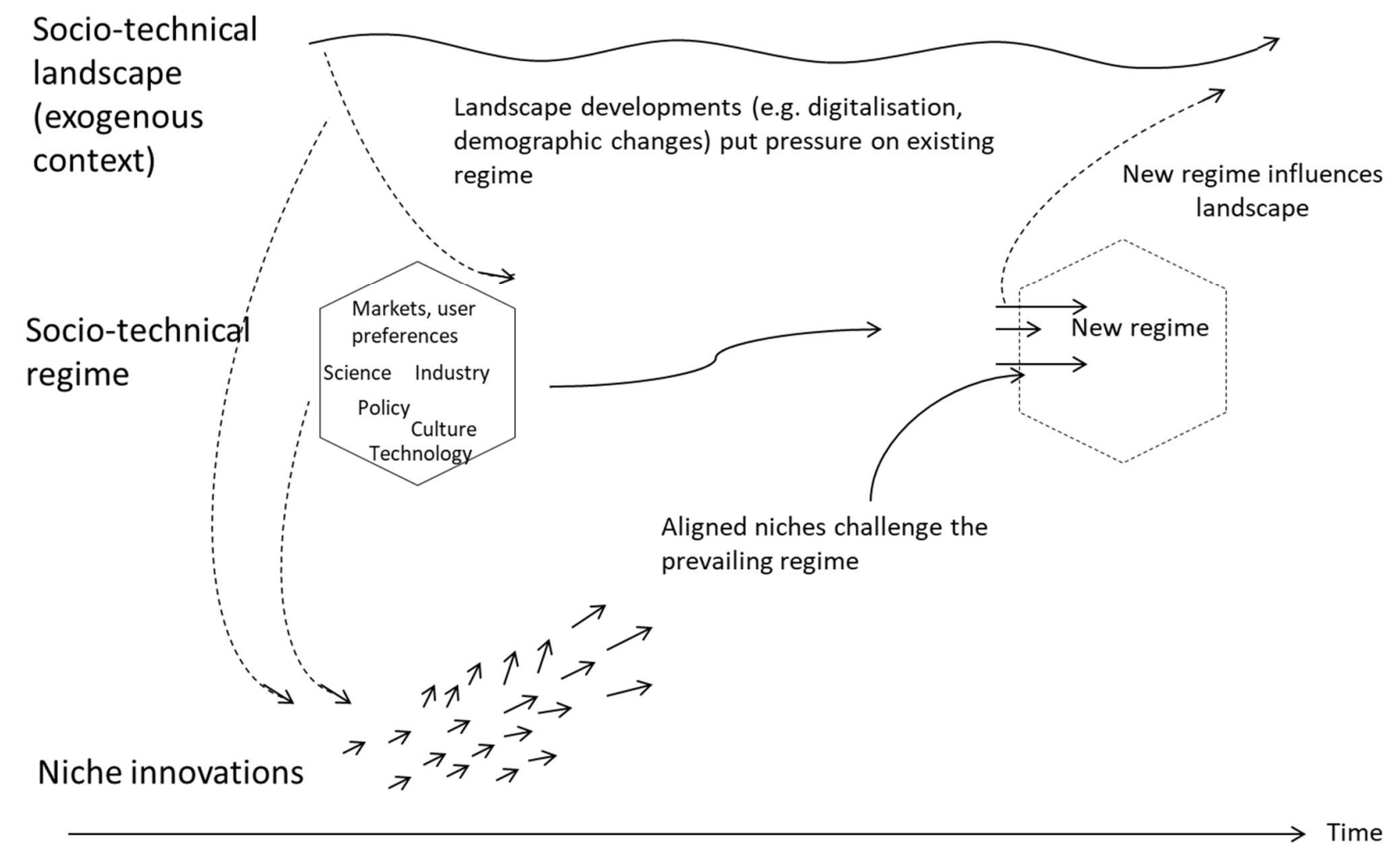

Figure 1. Multi-level perspective on transitions (modified from Geels, 2002; Geels \& Schot, 2007)

Changes at the landscape level include, for example, macro-economic changes, deep cultural patterns and macro-political developments. They exert pressure on the meso-level, the sociotechnical regime, and may make it unstable (Geels \& Schot, 2007). The sociotechnical regime includes markets, user preferences, regulations and laws, scientific understanding and political and cultural climates. It also includes technology and infrastructure aimed at fulfilling single societal functions (Geels, 2005), such as elderly 
care. The sociotechnical regime refers to the rule systems that guide and orient the activities of social groups, including scientists, users, policy makers and other actors, who interact and form networks with mutual dependencies (Kemp et al., 1998; Geels, 2005; Geels \& Kemp, 2007, p. 442). Applied to the context of elderly care, the elderly-care regime comprises people's preferences as related to the products and services that they use and consume, and the market and public sector's responses to those wishes and requirements. It also comprises the elderly-care industry, infrastructure and service structures, products (using both high and low technology) and current ways of producing services.

Niche innovations, i.e., radical novelties, form the MLP's micro-level. Niche innovations are emerging social or technical innovations that differ radically from the products and practices in the prevailing sociotechnical system and regime. They can gain a foothold with particular applications, in various geographical areas or with the help of targeted policy support (Kemp et al., 1998; Geels, 2018). These radical innovations surface either in response to landscape changes or in a bottom-up fashion. When landscape changes destabilize the current regime, it creates a window of opportunity for these radical novelties. This is why niche innovations are called 'seeds for change' (Geels, 2005).

Uncertainty characterizes niches, as innovative practices have not yet resulted in best practices, rules and routines. Niche innovations that are supported by more actors and receive greater resources have higher degrees of momentum (Geels, 2012). System transformation occurs when niches gather sufficient momentum so that these relatively loose configurations become institutionalized and create capacity, allowing emerging technologies and practices to challenge and re-institutionalize the regime (Bugge et al., 2017). Examples of niches in health care and elderly care include service robots, various monitoring devices, technology for self-diagnosis and novel service configurations or care-work practices. These novel service configurations and practices may include empowering and activating methods for the elderly, and promising examples exist of a remarkably decreased need for long-term inpatient care and medication based on them (Finne-Soveri, Pohjola, Keränen \& Raivio, 2014).

The role of niches is important in sociotechnical transitions, as examined in extant strategic nichemanagement (SNM) literature (Kemp et al., 1998; Schot \& Geels, 2008). Related concepts describing niche-regime interaction include upscaling, linking, socio-technological translation and niche-regime translation (Smith, 2007). Also, the concepts of societal embedding (Kivisaari, Lovio \& Väyrynen, 2004) and niche anchoring (Elzen, van Miero \& Leeuwis, 2012) provide highly similar content. Niche development is a necessary, but insufficient, precondition for a regime shift (Berkhout, Wieczorek \& Raven, 2011). The mechanisms through which niches contribute to regime reconfigurations are not yet clear (Bui, Cardona, Laminen \& Cerf, 2016), and a need exists for greater in-depth insight into how niches interact with regimes (Smink, Negro, Niesten \& Hekkert, 2015). However, in addition to actual niche development, niche-regime interaction is a key process in a transition because new rules and practices are integrated into the regime through it (Bui et al., 2016). The selection of new technologies and innovative practices is more than mere adoption. Users also must integrate novelties into their practices, organizations and routines (Geels, 2002), and niches frequently collide with the regime because of existing practices' inertia and lock-ins.

Geels (2018) emphasizes that the focus of transition studies should be shifted from 'singular disruption' to 'multiple innovations' and 'system reconfiguration' (Markand \& Truffer, 2006). The analysis should be broadened from niche innovations toward a better understanding of alignment with regime developments, including degrees of lock-in, tensions, destabilization and incumbent reorientation. 
Incumbent actors can resist, delay or derail transitions, but they also can accelerate them if they orient their strategies and resources toward the niche innovation (Geels, 2018). Geels encourages the study of niche-regime interactions bi-directionally, viewing them as multi-dimensional struggles between niche innovations and existing regimes. These struggles include economic competition between old and new technologies; business struggles between new entrants and incumbents; political struggles over adjustments in regulations, standards, subsidies and taxes; discursive struggles over problem framing and social acceptance; and struggles between new user practices and mainstream ones. Besides socio-political and discursive dimensions, the techno-economic and business dimensions also should be addressed in niche-regime interactions (Geels, 2018).

\section{Empirical context: regime description and upcoming niches}

\subsection{Elderly care in Finland}

Social and healthcare services' operational environment is experiencing changes in many societies. According to Oborn and Barrett (2016), two contemporary trends have the potential to reshape healthsystem delivery significantly in the coming decade. The first is digital health and big-data science, and the second is increasing patient and citizen engagement. These trends are related strongly to increasing citizen responsibility, co-production of information, usage and mastery of one's own health data, and digitalization of (self-) services. These trends also will play a major role in ongoing social and healthcare reforms in Finland, where the structure of social and healthcare services will be revamped over the next few years.

In Finland, social and healthcare services traditionally have been the public sector's responsibility, mainly that of municipalities. Currently, financial resources for social and healthcare services come from various sources, from which they are channeled to service agencies via different providers. The principal resource providers for healthcare services include central and local governments, the Social Insurance Institution of Finland, households, employers, wage earners and private insurance companies. Social services mainly are financed by the central government, local governments and clients themselves (Regional Government, Health and Social Service Reform, 2018).

Within the planned reforms, existing multi-source financing of social and healthcare services will be simplified, and users will be given greater freedom of choice. The responsibility for providing public social and healthcare services will be assigned to autonomous regions that are larger than municipalities. The public sector's role will change, as the reforms aim for private and non-governmental sectors eventually to increase services provided. According to policy goals that the present government has formulated, the objective is to reduce health and well-being gaps, safeguard the equal provision of social and healthcare services throughout the country, and create preconditions for reducing the economicsustainability gap by managing costs (Regional Government, Health and Social Service Reform, 2018).

\subsection{Digitalization and upcoming (technological) niches in elderly care}

As in many other countries, digitalization plays a major role in social and healthcare reforms in Finland. The government has adopted strategies for implementing digitalization of government and public services, as well as introducing related ICT operations in social and healthcare services and local governments. The 
objective is to support both users and professionals via efficient information systems and new e-services. Services are produced in a new manner that optimizes service processes with the help of digital tools. The e-services' objective is to help citizens maintain their well-being and health (Regional Government, Health and Social Service Reform, 2018). However, concerns have arisen regarding citizens having equal opportunities for access to digital services, as well as new demands and requirements for care professionals' changing work tasks, such as online chats and service-advisor roles, stimulating critical discussion (Hyppönen \& Ilmarinen, 2016).

Overall, high hopes have been placed on digitalization and gerontechnological innovations, such as ehealth, various types of monitoring, home automation, robotics and other simpler applications (Pekkarinen \& Melkas, 2017). E-health and health-information technology traditionally have supported patients by providing better access to records, integrated diagnostics and information searches, but nowadays, patients can engage with their health and other care services in new ways, e.g., through social media. In doing so, patients and service users also are creating new forms of data, evidence, knowledge and support, which can offer value to various stakeholders (Oborn \& Barrett, 2016). However, a research gap exists on how to handle this area at the strategic level. Thus, in addition to hardware (different kinds of assistive technologies), software (information systems) and combinations of the two, digitalization includes human factors and practices as an important element.

\section{$5 \quad$ Methods}

\subsection{Multiple-case study}

Our study was based on three case studies, all conducted in Finland and characterized by various types of technology in different living environments with elderly people. These technologies were used with the intention of finding innovative and sustainable solutions that would benefit the elderly, as well as their caregivers. The case studies entailed the following: (1) implementing tablet computers in senior housing; (2) construction of a multi-sensory room in a care home; and (3) use of a care robot in care homes and a rehabilitation hospital. By considering the perspectives of management, care professionals and elderly end-users in these case studies, we identified several critical factors in sustainable implementation and use (related to affordability, accessibility, acceptability, quality and adaptability) (Toebes, 1999; Grin \& Broerse, 2017; Fineberg, 2012) of technologies for elderly care and in the scalability of these technologies.

A multiple-case study was used as the principal method in our empirical examination. In this approach, a contemporary phenomenon is investigated in depth within its real-life context (Yin, 2009). In case-study research, data collection typically is extensive and draws on multiple sources of information (Creswell, 2007). The empirical data for this study include data collected via sessions, workshops and surveys, and written material that the case organizations produced. Additionally, in case study 3 , semi-structured focusgroup and individual interviews were conducted. The semi-structured interview themes were formulated based on theoretical knowledge and observational evidence from the implementation period.

In the following passages, the three case studies are described in greater detail:

(1) Implementing tablet computers in senior housing 
Case study 1 focused on the construction phase of a new 'smart house' (a block of flats) and the technological solutions contained in it. A particular novelty was the introduction of tablet computers, provided for each apartment in the new building. The clients were involved in the development process, e.g., in workshops, where their needs and expectations for their living environment and technology therein were mapped out. These needs and expectations included promoting a sense of community and the use of mainstream technologies in addition to 'pure' assistive technologies. Based on these needs, the organization decided to purchase ordinary tablet computers for each apartment in the newly built house (Figure 2). Students from a local vocational educational institution provided instruction on the use of the tablets. A communication channel (app) was installed on the tablets, but otherwise, they could be used as ordinary tablets. The new house was equipped with other technologies (smart elevator, automatic lighting, video entry phones, well-being wristbands, etc.) as well, but these were not the focus of this study.

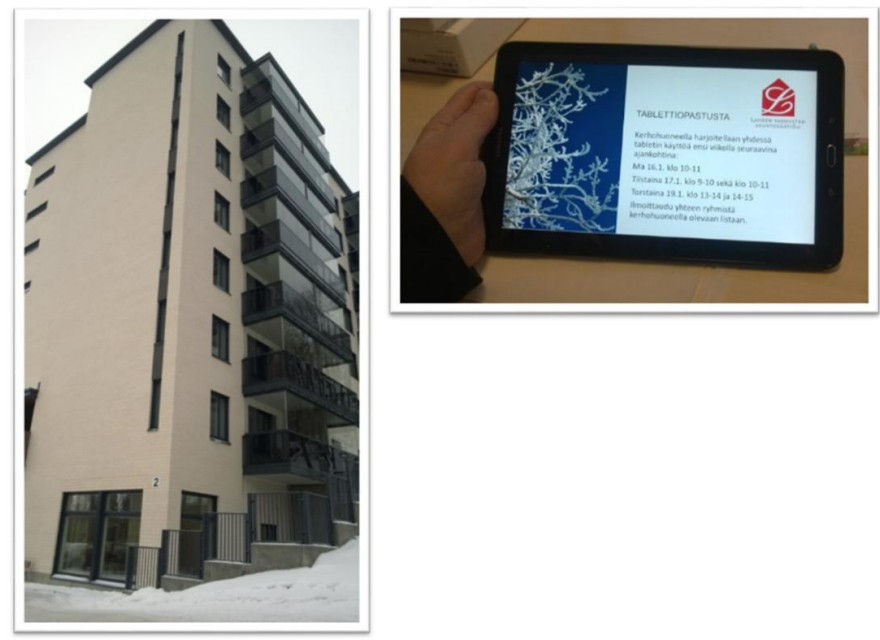

Figure 2. The new smart house and a tablet computer (Photos: Satu Pekkarinen)

(2) Construction of a multi-sensory room in a care home

Case study 2 focused on the development phase of a multi-sensory room, a physical area that was designed as an area for relaxation. The room can be arranged to provide a multi-sensory or single-sensory experience by adapting the lighting, atmosphere, sounds, photos, scents and textures to each ageing person's specific needs at the time of use. Mobile technology was integrated into the room through a 55inch Android tablet. The primary purpose was to create a comfortable environment (Figure 3 ) in which elderly people can relax or enjoy pleasant activities. In the future, when the experience of enjoying the room and its services becomes more commonplace, the objective might include reducing elderly people's medication consumption. The development process was conducted in collaboration with technology providers, designers, care professionals, elderly people and the researchers. 

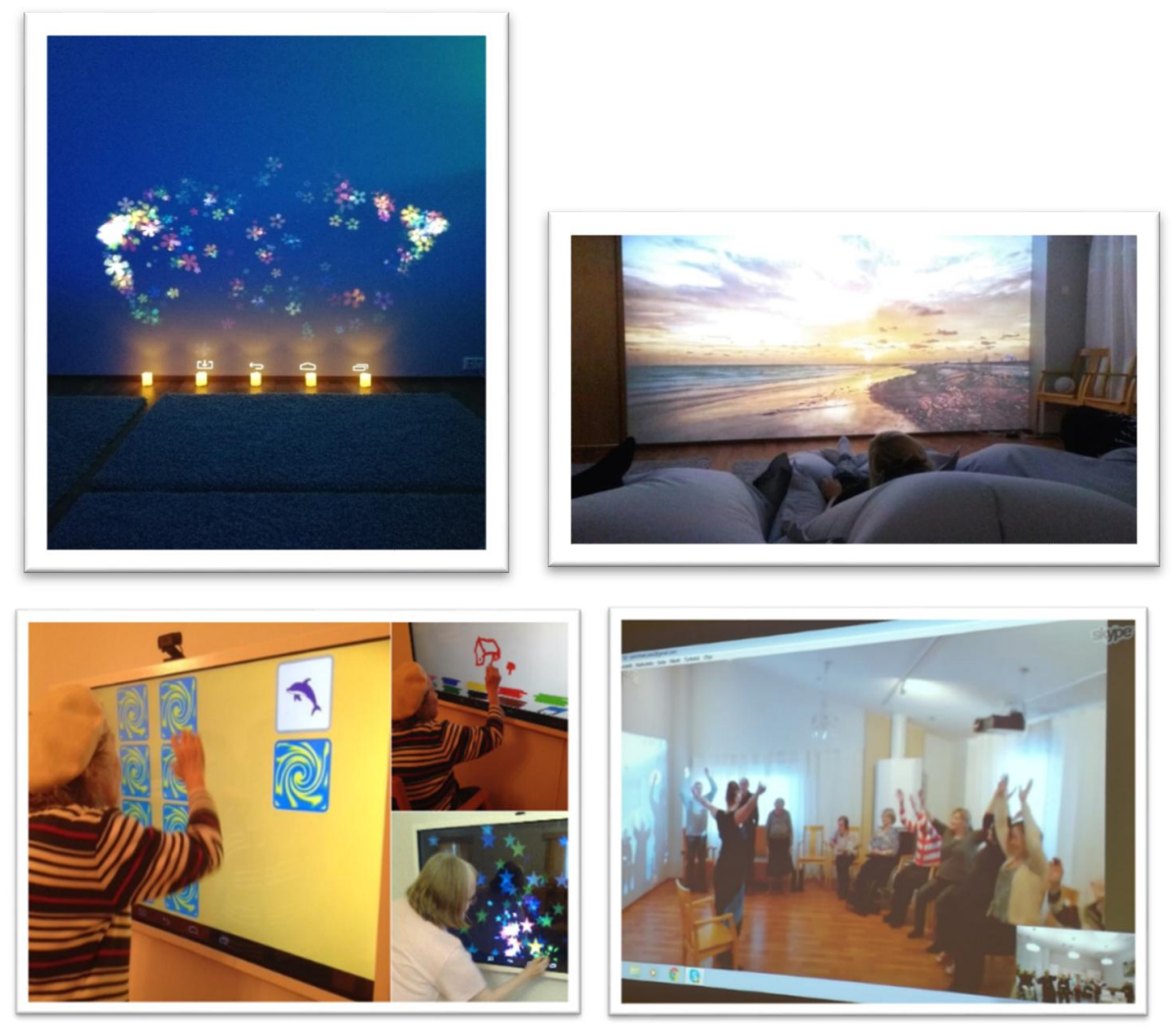

Figure 3. Multi-sensory room showing the tablet and activities (Photos: Päivi Ahonen, Mirva Hyypiä \& Satu Pekkarinen)

(3) Use of a care robot in care homes and a rehabilitation hospital

Case study 3 focused on the implementation phase of a care robot named Zora, a 57-centimetre-tall humanoid robot (Figure 4) that can be used for rehabilitation and recreation. It is operated through a tablet or another computer, and it has sensors, a speech synthesizer, microphone, camera and speakers. The robot features human-like characteristics: It walks, moves its hands while speaking and blinks its eyes. It is preprogrammed to perform several functions, but it also is possible to program the robot with the help of visual icons on the interface. No technical programming skills are required to use it.

During the implementation period, the robot was used for rehabilitation in two care homes and in a geriatric hospital. The robot either was introduced to the clients in a special session, or it played a part in routine group activities (exercise or literature groups) organized for the clients. In the care homes, a group of two to four physiotherapy or nursing students operated the robot, and in the hospital, a physiotherapist or nurse operated it. The robot facilitated exercises, played music, told stories, performed dances and played interactive memory and guessing games with elderly clients (see also Chapter 10). 


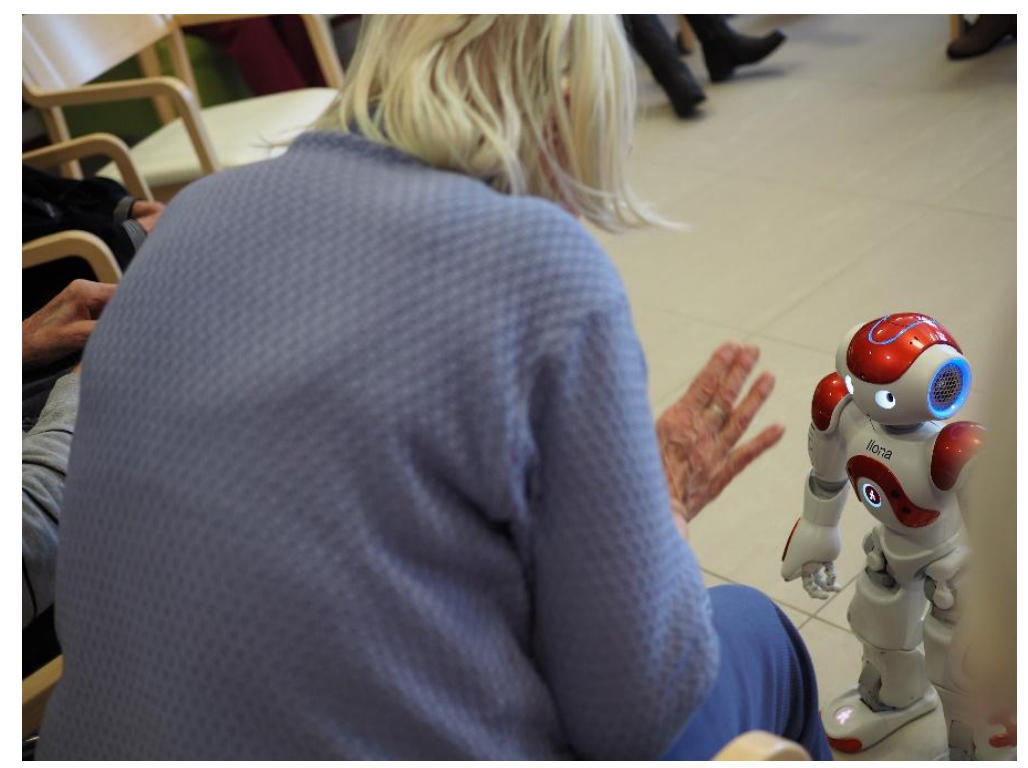

Figure 4. Zora (Photo: Satu Pekkarinen)

\subsection{Data collection and analysis}

Regarding data collection, a case study requires the use of multiple sources of evidence and often is used to contribute to our knowledge of individual, group, organizational, social and related phenomena. Having multiple sources of data helps address the issue of construct validity because multiple measurements of the same object are provided (Yin, 2009). Construct validity is guaranteed through the triangulation of multiple sources of evidence, chains of evidence and participant checking (Yin, 2003; Yazan, 2015).

The data from case studies 1 and 2 were collected during two organizations' development processes in 2015-2017: the Lahti Foundation of Housing and Services for the Elderly in the Päijänne Tavastia region in Southern Finland (case study 1) and the Service Centre Foundation of Lappeenranta in South-Eastern Finland (case study 2) (Table 1). Both of these non-profit organizations provide housing and other services for elderly people, and they are future-oriented and interested in utilizing technology in developing their services. The data were collected through participatory observation, including comprehensive notes and photos taken during the workshops and meetings. In case study 1 , inhabitants' experiences with tablets also were collected via a survey between April and May 2017. Health care personnel distributed the written survey forms to each apartment. In case study 2, students from Saimaa University of Applied Sciences helped the case company organize an additional testing session in the multi-sensory room for care personnel, visiting senior citizens and fellow students. The session was organized in April 2017, and participants' feedback was collected through a written survey at the end of the session. In addition, an audiovisual workshop via Skype, in a collaboration between cases 1 and 2, was organized in February 2017. Four care professionals, a researcher and 22 residents from Lahti and Lappeenranta participated in the Skype workshop. In all three case studies, the researchers were not mere observers, but also participated in the sessions and workshops as planners, participants or facilitators. Their participatory positions within the study naturally influenced the way that data were interpreted, but the authors' roles within the cases varied, e.g., they took part simultaneously or separately in the sessions and workshops as 
developers or facilitators. Different roles in a multiple-case study enable researchers to view the case studies from various perspectives and explore differences within and between cases.

The data for case study 3 were collected in a field study conducted within municipal elderly-care services in Finland between December 2015 and April 2016 (Table 1). During this period, the care robot Zora was introduced into elderly care services in the City of Lahti in Southern Finland. Data were collected during a 10-week test period, when the robot was introduced into the elderly-care environment. Researchers observed the activity sessions (Figure 5), each of which lasted about an hour, during which comprehensive notes and photos were taken. The researchers also observed care professionals' sessions, during which they planned the implementation phase and received training on how to use the robot. The topics of the semi-structured interviews with the care professionals, managers and health care students included primary reactions and experiences during the implementation and familiarization phases. They also included anticipated and experienced benefits and challenges, impacts on work practices and perceptions concerning the robot's suitability and applicability in aiding elderly inhabitants or care work. Interviews with five clients focused on their thoughts when they first saw the robot, e.g., its pleasant, surprising or irritating characteristics; differences in recreation sessions with or without the robot; and their willingness to participate in sessions with robots in the future.

The research was conducted using ethical standards to avoid any harm to participants. Both care personnel and clients consented to participate in the sessions and research. Leaving a session before it ended was permitted. Care professionals assisted clients, for instance, if any had mobility problems. Client safety was ensured by using technologies only under the appropriate and competent supervision of at least one care worker. The tablet computers were an exception to this rule, as the clients had them in their own homes. However, in this situation as well, intensive support was given. The research material was anonymized, and no personal or health-related information could be identified from the data. Healthrelated information about clients was neither sought nor obtained.

Table 1. Case-study descriptions

\begin{tabular}{|c|c|c|c|}
\hline Case study & Case-study experiments & $\begin{array}{l}\text { Main target } \\
\text { group }\end{array}$ & Data collection and participants \\
\hline $\begin{array}{l}\text { 1. Tablet } \\
\text { computers }\end{array}$ & $\begin{array}{l}\text { Construction of a new 'smart } \\
\text { house' for elderly people; } \\
\text { special focus on providing } \\
\text { tablet computers in the } \\
\text { apartments as a communal } \\
\text { communication channel. } \\
\text { The development work was } \\
\text { conducted together with the } \\
\text { technology providers, } \\
\text { designers, care professionals, } \\
\text { elderly residents and } \\
\text { researchers. }\end{array}$ & $\begin{array}{l}\text { Ageing people } \\
\text { living } \\
\text { independently }\end{array}$ & $\begin{array}{l}\text { Three workshops: technology in the } \\
\text { living environment in general ( } 21 \\
\text { elderly clients and four members from } \\
\text { personnel) } \\
\text { - Four workshops: orientation to the use } \\
\text { of tablets (19 elderly clients and one } \\
\text { care professional, as well as five to six } \\
\text { students providing guidance in tablet } \\
\text { use) } \\
\text { - Survey for clients (April-May 2017): } \\
29 \text { females and } 12 \text { males ages } 60 \text { to } 90 .\end{array}$ \\
\hline $\begin{array}{l}\text { 2. Multi- } \\
\text { sensory room }\end{array}$ & $\begin{array}{l}\text { Development of a multi- } \\
\text { sensory environment, }\end{array}$ & $\begin{array}{l}\text { Dementia-care } \\
\text { clients and care } \\
\text { professionals }\end{array}$ & $\begin{array}{l}\text { Three workshops and two seminars } \\
\text { among care professionals (three to } 10 \\
\text { care professionals per event) }\end{array}$ \\
\hline
\end{tabular}




\begin{tabular}{|c|c|c|c|}
\hline $\begin{array}{ll}3 \\
-3\end{array}$ & $\begin{array}{l}\text { especially for clients with } \\
\text { memory diseases. } \\
\text { The development process } \\
\text { included technology } \\
\text { providers, designers, care } \\
\text { professionals, elderly people } \\
\text { and researchers. }\end{array}$ & & $\begin{array}{l}\text { Three benchmarking visits and } \\
\text { briefings with collaborating companies } \\
\text { (company representatives, director, and } \\
\text { two managers and researchers) } \\
\text { - An audio-visual workshop via Skype } \\
\text { in a collaboration between case studies } \\
1 \text { and } 2 \text { (four care professionals, one } \\
\text { researcher and } 22 \text { clients from case } \\
\text { studies } 1 \text { and } 2 \text { ) } \\
\text { - Survey for participants in a testing } \\
\text { session (April 2017); with feedback } \\
\text { from } 35 \text { respondents, including care } \\
\text { professionals, visitors and fellow } \\
\text { students }\end{array}$ \\
\hline 3. Care robot & $\begin{array}{l}\text { Introduce a service robot in } \\
\text { public elderly-care services } \\
\text { in care homes and a geriatric } \\
\text { rehabilitation hospital. } \\
\text { Finding appropriate ways to } \\
\text { use it and orient personnel } \\
\text { toward its use. }\end{array}$ & $\begin{array}{l}\text { Elderly people/ } \\
\text { clients in a } \\
\text { geriatric } \\
\text { rehabilitation } \\
\text { hospital and in } \\
\text { care homes that } \\
\text { provide } \\
\text { around-the- } \\
\text { clock care } \\
\text { services }\end{array}$ & $\begin{array}{l}\text { Participatory observations of the robot } \\
\text { being used for rehabilitation purposes } \\
\text { at two 24-hour service-care homes and } \\
\text { at a geriatric-rehabilitation hospital (27 } \\
\text { activity sessions) } \\
\text { Focus-group interviews with the care } \\
\text { professionals ( } 35 \text { people), individual } \\
\text { interviews with three members of } \\
\text { management and group interviews with } \\
\text { five clients and six health care students }\end{array}$ \\
\hline
\end{tabular}

Content analysis was used to analyze the data. The analysis was based on occurrences of mutual themes, contradictory feedback, experiences and suggestions for improvements, with specific attention paid to issues related to sustainability (social and economic aspects) in technology implementation. The researchers analyzed all the data, both independently and collectively. In addition, the data were discussed with the participants from the case organizations at various meetings related to the projects. 


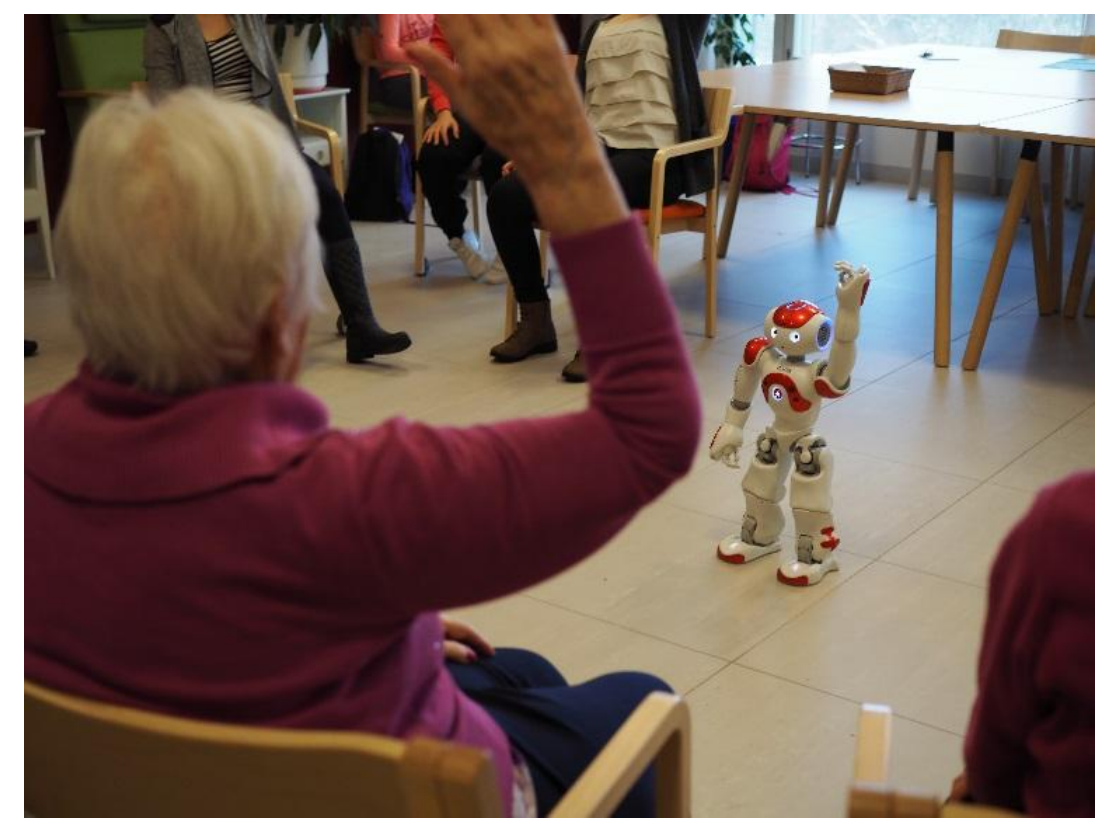

Figure 5. The robot in action during an exercise session (Photo: Satu Pekkarinen)

\section{$6 \quad$ Results}

The selected case studies represented niches in which technologies were applied in ways that were responsive to the challenges brought by landscape-level changes in elderly care. In the following section, critical factors in the niche development of the selected case studies are identified, and the conditions for their scalability in terms of niche-regime interaction are examined.

\subsection{Case study 1}

Niche development

Case study 1's objective was to introduce tablet computers into senior housing for use as a communication channel and also to familiarize older people with new technologies, thereby preventing a sense of digital exclusion. As pieces of technology, tablet computers may be considered mainstream, but providing them to all inhabitants in a block of senior flats, then using them as a communication channel, can be considered a niche.

The experiences from this case study showed that, considering that the end-users were elderly inhabitants, critical success points are adequate support for and meaningful content of this technology, e.g., relating the use of the tablet to personal interests and hobbies. Resources for learning (both technological and time) need to be provided. In this particular case, these issues were considered carefully, and the participants mostly felt that they had received sufficient support for their tablet use. 
Another critical point in the case's success was the openness of the participating personnel: prejudices and stereotypical views related to ageing people's learning skills should be questioned. This does not mean that the possible restrictions that accompany ageing should be overlooked, i.e., they need to be considered. According to a survey among inhabitants, $91 \%$ of the respondents thought that having a tablet was a good thing (Pekkarinen, Hyypiä, Melkas \& Mäkinen, 2017). Residents who were nearly 90 years old learned how to use these tablet computers, raising interest in other kinds of technology as well (Pekkarinen et al., 2017). In the development of a niche innovation, user participation and related learning are crucial. Learning to use a tablet can be a social process that includes interacting with peers. Supporting this kind of social practice was considered important in this case. This highlights the fact that technology use should be tied in with different kinds of practices. In addition to technological skills, the users also need cultural skills relating to the practices. Using social media is an illustrative example. Data protection needs to be learned, too. Implementing technologies while simultaneously developing services is challenging for management. Generally, management plays a vital role in how services and technologies are enabled to function together.

\section{Niche-regime interaction}

If tablet computers in senior housing are to be diffused and scaled up into a regime practice, questions about resources for purchasing the technology and for providing the necessary support should be addressed. The positive experiences from this implementation case have raised interest among regime actors, especially because of its societal impacts in narrowing the digital divide between generations. However, questions about resources remain: Who should pay for tablets for the elderly, and who should provide the introductions and orientations needed? Stereotypical views also persist regarding elderly people's needs and abilities. It is still common for elderly people (or care institutions) to be offered only different kinds of assistive technologies, which have a very different and considerably higher price structure than mainstream technologies. However, as this case shows, many elderly people also are capable of using mainstream technologies and benefitting from them, with no need for special and expensive solutions.

\subsection{Case study 2}

\section{Niche development}

Case study 2's objective was to develop a multi-sensory room for a dementia unit and provide a relaxing and calming atmosphere for inhabitants by adapting the lighting, atmosphere, sounds, photos, scents and textures to the specific needs of the particular ageing person using it. The biggest challenge in this niche development was related to finding suitable technologies for this holistic concept. These had to be collected from different sources, and the various technologies had to be combined and used differently from how they were used in their original context.

The crucial challenge here was related to the ability to combine and coordinate the collaborators' diverse forms of knowledge and expertise. In addition, many of the technology providers did not have any prior experience with elderly care. Furthermore, a challenge was to coordinate the different experts in the network (working in different organizations), as well as enable them to understand and collaborate toward a common objective. 
As in case study 1 , management played an important role. The managers needed to be committed and present during the development process. The personnel had a chance to purchase various pieces of equipment and the necessary expertise during the development process, but this required that management give them permission to invest in these facilities. Case study 2 also showed that the more the equipment, solutions and elements are combined, as happened in the development of the multi-sensory room, the more knowledge and skills the users are required to have.

This applied both to the development process and to the use of end results. When assessing suitable technologies and designing their possible combinations, a multi-faceted understanding, which included both knowledge and skills, was needed. The multi-technology development process required in setting up the multi-sensory room could be viewed as a small 'laboratory' of technology-design processes, which typically suffer from coordination challenges and shortcomings in finding suitable combinations. Therefore, the lessons learned will be valuable in future scaling up.

\section{Niche-regime interaction}

Referring to the aforementioned observations, at least two types of diffusion and scaling up seem to be needed. First, there is a need to view the older person's well-being and quality of life from a holistic perspective and in a proactive manner. Second, the need exists to contribute to building meaningful wholes from various technological 'bits and pieces'. As in case study 1, these worthy objectives may be thwarted by difficulties in finding resources for purchasing the technology. Support is needed to make it possible to use the technologies smoothly, but even more important is the objective of building meaningful wholes from disparate technologies. These two types of diffusion can contribute to sustainability, but they would require longer-term understanding and support, which usually create a bottleneck at all levels of decisionmaking.

Longer-term understanding also is needed to overcome possible collisions with current regime practices. One of the multi-sensory room's long-term objectives, with its calming effect, is the possibility of elderly residents reducing their medication doses. However, medication supply is also a business, so some current regime actors might not support such reductions. Wherever such conflicts of interest exist, they should be made visible and the basic objectives of humane care highlighted.

\subsection{Case study 3}

\section{Niche development}

The principal objective of this case was to introduce a care robot, Zora, into municipal elderly-care services for use in rehabilitation and recreation (see also Chapter 10). Another objective was to find new purposes for how the robot could be used in elderly care. During the implementation phase, two attitudes toward the robot were noted: For some of the care professionals, the robot was perceived as a useful tool, contributing to clients' well-being and activity and providing new perspectives and content on their work. Some care professionals were enthusiastic about having a new 'workmate' and were willing to act as the principal operators of the robot in their work communities, including giving up their free time to become acquainted with the robot. Conversely, for other employees, having the robot in the work environment represented the possibility of risk, even danger, leading to their withdrawal from the implementation. 
Some employees felt that the robot was just a waste of money and created additional work when their workday already was too busy. Moreover, concerns surfaced about the time used and the commitment from the whole working community, and how being occupied with using the robot would detract from 'true' care work. These attitudes led to tensions and controversies in the work communities. The care professionals also raised ethical concerns. Some even felt that the 'childish' robot was degrading to the elderly.

However, the clients usually welcomed the robot with joy, and these positive responses and the interest from elderly clients affected care personnel's attitudes positively. It was noted that after having personal experiences working with the robot, staff attitudes turned in a more positive direction. One nurse said: 'At first, I had a few negative feelings, but when I saw the joy of the clients, it changed my attitude'. According to a physiotherapist, 'Robot use requires supervisors and work, but do we depart from what we give to clients? I cannot tolerate technology, but still, I have a positive attitude if I see that the customer gains something good out of it. You have to reach beyond your own attitude'.

Regarding management, sufficient planning is needed, and time should be allocated for using a robot in work communities. The robot must not cause undue extra work for caregivers, so this needs to be planned carefully. Also, plenty of prejudices and fears regarding robots remain. Such anxieties must be taken seriously, but they can be smoothed out, e.g., through effective orientation (Pekkarinen \& Hennala, 2016). It is more likely that robots will be accepted as part of a 'care regime' with each new pilot program and more experience gained.

It was found that an 'interpreter' was needed to help the robot and clients understand each other, requiring new skills from personnel. On balance, the multi-faceted and effective use of a robot requires time and resources, although basic functions can be learned quickly. This is a central finding in relation to sustainability. One of the interpreter's tasks was that she or he needed to bring transparency to usage situations, such as clarifying who was talking when the robot was talking and how the robot functioned. Furthermore, various technical issues need to be addressed: a good Internet connection is needed; the robot's voice can be too quiet for older people to hear; and the robot may not hear what the older people say, may misunderstand their dialects, etc.

\section{Niche-regime interaction}

Several issues were noted during this niche experiment that relate to the present regime. As noted during the implementation phase, attitudes toward robotics in elderly care vary: Robots are viewed as both opportunities and threats. These attitudes are related, for instance, to quality of care, ethical issues and work division between human beings and robots (Tuisku, Pekkarinen, Hennala \& Melkas, 2017). Attitude polarization exists at both the niche and regime levels.

The nursing and physiotherapy students who operated the robot and were responsible for planning the robot's interactive exercises and activities with elderly residents considered the task very interesting. They were interested in technological opportunities in care, but they mentioned that technology had not played a significant role in their education or in the curriculum. The use and design of the robot required that existing personnel develop new skills. Therefore, such issues should be considered, both in the education of future professionals and in the continuous education or short-term training of current professionals. In addition, developing technological skills in care-related education probably would contribute to the 
diffusion and scaling-up of these technologies. The multidisciplinary nature of such education and training also would be valuable. In case study 3 , the importing company provided the training on how to operate the robot, but its representatives were physiotherapists, not engineers. Such cross-disciplinary competencies are likely to be valued increasingly in the working life of the future, which also requires new practices in education.

Apart from people's attitudes and managerial issues, what hinders robot implementation and regime change most is the technologies' immaturity (e.g., Hennala et al., 2017). The robot's technologicaldevelopment process lies beyond the scope of this chapter, but it has been stressed in extant literature that users - in this case, older people, their caregivers and care managers - should be involved in the process to overcome some of the aforementioned shortcomings (e.g., Peine et al., 2015).

\subsection{Summary of results: Critical issues in niche development and implementation, and niche-regime interaction}

The results of the three case studies are summarized in Table 2. 
Table 2. Critical issues in sustainable implementation and diffusion of technologies in elderly care, on the basis of the three case studies

\begin{tabular}{|c|c|c|c|c|}
\hline $\begin{array}{l}\text { Niche development and } \\
\text { implementation: Elderly } \\
\text { end-users }\end{array}$ & $\begin{array}{l}\text { Niche development } \\
\text { and implementation: } \\
\text { Care professionals }\end{array}$ & $\begin{array}{l}\text { Niche development and } \\
\text { implementation: } \\
\text { Managers in care } \\
\text { facilities }\end{array}$ & $\begin{array}{l}\text { Niche development and implementation: } \\
\text { Technological/infrastructure-related perspectives }\end{array}$ & Scalability/Niche-regime interaction \\
\hline $\begin{array}{ll}\text { - } & \text { Willingness and } \\
\text { motivation } \\
\text { - Time, effort and } \\
\text { support, also from } \\
\text { the families } \\
\text { Encounters via } \\
\text { personal interests } \\
\text { - Need for knowledge } \\
\text { about various } \\
\text { practices and } \\
\text { cultures related to } \\
\text { technology use } \\
\text { - Critical issues also } \\
\text { depend on the } \\
\text { 'phase' of old age } \\
\text { (e.g., health } \\
\text { condition) and } \\
\text { family } \\
\text { circumstances }\end{array}$ & $\begin{array}{ll}\text { - Attitudes toward } \\
\text { technologies in } \\
\text { care, e.g., fear of } \\
\text { robots replacing } \\
\text { nurses } \\
\text { - Explaining the } \\
\text { technology used } \\
\text { with clients } \\
\text { (transparency) } \\
\text { - Proper training } \\
\text { and time } \\
\text { allocation made } \\
\text { for learning } \\
\text { - Ability to use the } \\
\text { technologies and } \\
\text { facilities } \\
\text { - Support in use }\end{array}$ & $\begin{array}{ll}\text { - } & \text { Skills and expertise: } \\
\text { information about } \\
\text { new technologies } \\
\text { - Networking skills in } \\
\text { development } \\
\text { projects and in } \\
\text { purchasing } \\
\text { processes } \\
\text { - Ability to combine } \\
\text { and coordinate } \\
\text { diverse forms and } \\
\text { expertise of } \\
\text { collaborators } \\
\text { Ability to meet and } \\
\text { understand clients } \\
\text { and care } \\
\text { professionals, } \\
\text { different views and } \\
\text { needs related to } \\
\text { technology } \\
\text { - Provision of time for } \\
\text { learning and support }\end{array}$ & $\begin{array}{l}\text { - Utilization of mainstream technologies in } \\
\text { addition to 'pure' assistive technologies } \\
\text { Knowledge about contexts/user groups, with } \\
\text { tailoring of technologies according to user } \\
\text { groups } \\
\text { Availability of technologies/facilities } \\
\text { - Compatibility of different technologies and } \\
\text { dependence on external resources, such as } \\
\text { Internet connection providers } \\
\text { - Support for finding appropriate combinations } \\
\text { of technologies } \\
\text { - Development and maintenance of technologies } \\
\text { is expensive (despite high prices, technologies } \\
\text { may still be in progress) } \\
\text { The possibility of tailoring technologies to } \\
\text { customers' needs and only paying for the } \\
\text { properties that one needs } \\
\text { Questions of maintenance and support? Are } \\
\text { those guaranteed? }\end{array}$ & $\begin{array}{ll}\text { - } & \text { Considering the heterogeneity of } \\
\text { the elderly and seeing quality of } \\
\text { life and well-being in old age in } \\
\text { a holistic manner } \\
\text { - } & \text { Support for purchasing processes } \\
\text { - } & \text { Funding models (the question of } \\
\text { costs on a larger scale) } \\
\text { - } \\
\text { Attitudes toward technologies in } \\
\text { care (especially robots) } \\
\text { - } \quad \text { Understanding of the whole of } \\
\text { technology (mainstream } \\
\text { technologies, specific care } \\
\text { technologies, even non-digital } \\
\text { assistive technologies) and their } \\
\text { possible combinations } \\
\text { - Inclusion of technology in } \\
\text { education for care, as well as } \\
\text { other educational reforms } \\
\text { Integration of users into } \\
\text { technology development }\end{array}$ \\
\hline
\end{tabular}




\section{$7 \quad$ Conclusions and discussion}

Moving toward a transition in elderly-care services is a systemic issue. In this chapter, we spotlighted the case studies' sustainability aspects, as well as the conditions in which niche innovations can develop and diffuse to challenge the prevailing regime. Increasingly, sustainable elderly care requires that attention be paid to (1) niche-development practices, co-creation, agile development and co-evolution of technologies and services in niches, and (2) niche-regime interactions so that individual best practices can become mainstream practices to scale up and contribute to regime transformation. What does this entail, i.e., what hinders or facilitates implementation of relevant technologies? General issues were introduced in the results, but they need to be acknowledged in different ways through individual technology-related design and use processes, with attention paid to users, care professionals, managers and policy makers. Already in 2009, Raappana and Melkas have said that it is time to start lobbying for a holistic view of technology use in elderly care, as otherwise rapid technological change could lead to increasingly fragmented solutions that drift further and further apart from each other. A major change in direction is needed, as the past 10 years have not seen much improvement, with good practices remaining isolated from each other.

Our case studies demonstrate that the sustainability of elderly care and the implementation of technology are systemic challenges. The role of technology in the sustainability of care seems to be somewhat ambivalent, and in this sense, it is part of the challenge's wickedness. For instance, related to the quality and acceptability aspects of social sustainability, fears exist that the use of technology reduces the human touch in care and is not part of the 'true essence' of care work. However, on the other hand, the use of technology may increase peer contacts, as well as care contacts, if technology helps care personnel in those routine-like tasks that are not social in nature and, for instance, reduce the need to move from one place to another. Thus, it is a question of good division of work between a human and technology.

Even though the need for change in elderly care is recognized, several critical issues can either hinder or facilitate implementation of relevant technologies. These issues often are related to lockins in existing practices, while the practices would need to change simultaneously with the implementation of new technologies, which requires allocation of time, as well as new skills and expertise for elderly users, care professionals and managers. Thus, the question is not merely about technological expertise, but also about the willingness to create new practices, as well as reconsider certain prejudices regarding the elderly's capabilities.

The starting point for systemic development is very different if the new technologies can be combined with existing infrastructures and practices, or whether the process must start from scratch. The risk of collisions and a need for compromise always exist -often at the expense of usability issues - when too many preconditions must be considered in the planning process. Wherever it is possible to develop a new technology and a new service concept without preconditions, it is far easier to develop a technology and service that support each other right from the start. 
Attitudes toward technology in elderly-care work are divided: Both enthusiasm and fears are common, with the role of technologies in the field of care still undefined in many ways. The potential remains for sustainable care if usage is well-planned. Where technology is included in the management of sustainable elderly care, it is crucial that the technology's objectives are clear, and that care personnel and clients all acknowledge these objectives. Time must be allotted for learning, and the implementation of technologies in elderly care requires a rethinking of services and work practices. It is an issue that should involve the whole community. Orientation is a major issue that needs to be highlighted and dealt with skillfully in this process. Services for the ageing population may benefit from technology, but smart and sustainable use of technology requires planning and human resources. Sustainability must be approached from the perspective of its four aspects: social, economic, cultural and environmental.

The transition related to ageing should be viewed from a wider perspective, not just in terms of social- and health-care, but from a life-based perspective. Old age is a long period with different stages and orientations (Laslett, 1989; Gilleard \& Higgs, 2002). Östlund, Olander, Johnsson and Frennert (2015) also noted this, emphasizing that as technology users, older people often are viewed stereotypically or approached in the context of assumptions and static identities. Sustainable solutions need to adapt to the reality that many older people are comfortable using technology. Sustainable ageing depends on participating in preventive activities during the whole lifespan, which includes participation in society. An example of lifespan thinking and preventive strategies is the Finnish guidance-center system for families with babies and small children. It was established in the 1950s, and the first infant clients are now reaching retirement age. In sustainable care, the perspective always should cover one's entire lifespan, while understanding the concerns of holistic well-being, not just focusing on 'repair work' at a certain age. If such thinking were linked to technologies, we might find the correct track at the societal level. Technology that supports intermediary housing models and adaptable lifespan living would be a practical example.

To help promising niches become aligned, and to increase their momentum during the transition, niche actors should aim to learn more systematically from previous experiments. It is not always necessary to use a completely new technology, as older technologies can be utilized in new and innovative ways and in new areas, as our results from case studies 1 and 2 indicate. Furthermore, simple solutions may prove to be the best way to achieve sustainability. This also would support the environmental aspect. When novel technologies, such as robots, are involved, both similar and different requirements concerning attitudes, competencies and the technology's maturity exist. Combining and skillfully using both older and newer technologies relate to what Geels (2018) highlighted when he spoke of the need to consider a wider perspective, rather than a singular disruption. Some of the multi-dimensional struggles between niche innovations and existing regimes have been presented in this chapter. Future research should aim to cover, for instance, the techno-economic and business dimensions through in-depth case studies.

\section{Acknowledgments}

This research was supported by Tekes, The Finnish Funding Agency for Technology and Innovation (project name: "Revolution of the Service Economy: Human Being at the Core of Digitalization"), the Strategic Research Council at the Academy of Finland (project name: 
"Robots and the Future of Welfare Services" [ROSE], decision numbers 292980 and 314180), and the LUT Research Platform on Smart Services for Digitalisation (DIGI-USER).

\section{References}

Auping, W.L., Pruyt, E., \& Kwakkel, J.H. (2015). Societal ageing in the Netherlands: a robust system dynamics approach. Systems Research and Behavioural Science, 32(4), 485-501.

Berkhout, F., Wieczorek, A. J., \& Raven, R. (2011). Avoiding environmental convergence: A possible role for sustainability experiments in late-comer countries? International Journal of Institutions and Economics, 3(2), 367-385

Bianchi, C. (2015). Enhancing joined-up government and outcome-based performance management through system-dynamics modelling to deal with wicked problems: the case of societal ageing. Systems Research and Behavioural Science, 32(4), 502-505.

Boström, M. (2012). A missing pillar? Challenges in theorising and practicing social sustainability: Introduction to the special issue. Sustainability: Science, Practice and Policy, 8(1), 3-14

Bugge, M., Coenen, L., Marques, P., \& Morgan, K. (2017). Governing system innovation: Assisted living experiments in the UK and Norway. European Planning Studies 25(12), 2138-2156.

Bui, S., Cardona, A., Laminen, C., \& Cerf, M. (2016). Sustainability transitions: Insights on processes of niche-regime interaction and regime reconfiguration in agri-food systems. Journal of Rural Studies, 48, 92-103.

Compagna, D., \& Kohlbacher, F. (2015). The limits of participatory technology development: The case of service robots in care facilities for older people, Technological Forecasting and Social Change, 93(19), 19-31.

Creswell, J. W. (2007). Qualitative Enquiry and Research Design: Choosing Among Five Approaches. Thousand Oaks, CA: Sage Publications.

Elzen, B., van Mierlo, B., \& Leeuwis, C. (2012). Anchoring of innovations: Assessing Dutch efforts to harvest energy from glasshouses. Environmental Innovation and Societal Transitions, 5, 1-18.

Essink, D. R. (2012). Sustainable Health Systems: The Role of Change Agents in Health System Innovation. Amsterdam, Netherlands: VU University.

Fineberg, H.V. (2012). A successful and sustainable health system - how to get there from here. New England Journal of Medicine, 366(11), 1020-1027.

Finne-Soveri, H., Pohjola, L., Keränen, J., \& Raivio, K. (2014). Pysyvästi aktivoivaan arkeen InnoKusti-hanke 2007-2010 ja miten sitten kävi. Helsinki: Terveyden ja hyvinvoinnin laitos. (In Finnish.)

Friedland, R. B. (2004). Caregivers and long-term care needs: Will Public Policy Meet the Challenge? Georgetown University Long-Term Care Financing Project, Issue Brief. Washington, DC: Georgetown University Press.

Geels, F. W. (2002). Technological transitions as evolutionary reconfiguration processes: A multi-level perspective and a case-study. Research Policy, 31(8/9), 1257-1274. 
Geels, F. W. (2004). Understanding system innovations: A critical literature review and a conceptual synthesis. In B. Elzen, F.W. Geels \& K. Green (Eds.), System Innovation and the Transition to Sustainability (19-47). Cheltenham, UK: Edward Elgar Publishing.

Geels, F. W. (2005). Technological Transitions and System Innovations: A Co-Evolutionary and Sociotechnical Analysis, Cheltenham, UK: Edward Elgar Publishing.

Geels, F. W. (2011). The multi-level perspective on sustainability transitions: Responses to seven criticisms, Environmental Innovation and Societal Transitions, 1(1), 24-40.

Geels, F. W. (2012). A socio-technical analysis of low-carbon transitions: Introducing the multilevel perspective into transport studies. Journal of Transport Geography, 24, 471-482.

Geels, F. W. (2018). Disruption and low-carbon system transformation: Progress and new challenges in socio-technical transitions research and the Multi-Level Perspective. Energy Research \& Social Science, 37, 224-231.

Geels, F. W., \& Kemp, R. (2007). Dynamics in socio-technical systems: Typology of change processes and contrasting case studies. Technology in Society, 29(4), 441-455.

Geels, F. W., \& Schot, J. W. (2007). Typology of sociotechnical transition pathways. Research Policy, 36(3), 399-417.

Gilleard, C., \& Higgs, P. (2002). The third age: Class, cohort or generation? Ageing and Society, $22(3), 369-382$.

Grin, J., \& Broerse, J. (Eds.) (2017). Toward Sustainable Transitions in Healthcare Systems. New York: Routledge.

Grin, J., \& Broerse, J. (2017). Introduction. In J. Grin \& J. Broerse (Eds.), Toward Sustainable Transitions in Healthcare Systems (1-20). New York: Routledge.

Gummesson, E. (2000). Qualitative Methods in Management Research. Thousand Oaks, CA: Sage Publications.

Hennala, L., Koistinen, P., Kyrki, V., Kämäräinen, J.-K., Laitinen, A., Lanne, M., ...\& Van Aerschot, L. (2017). Robotics in Care Services: A Finnish roadmap. Available at: http://roseproject.aalto.fi/images/publications/Roadmap-final02062017.pdf

Hyppönen, H., \& Ilmarinen, K. (2016). Sosiaali- ja terveydenhuollon digitalisaatio (Digitalisation in social services and health care). National Institute for Health and Welfare. Available at: https://www.julkari.fi/bitstream/handle/10024/131301/URN_ISBN_978-952-302-7398.pdf?sequence $=1$ (accessed 12 January 2018).

Kapadia, V., Ariani, A., Li, J., \& Ray, P. K. (2015). Emerging ICT implementation issues in aged care. International Journal of Medical Informatics, 84(11), 982-900.

Kemp, R., Schot, J., \& Hoogma, R. (1998). Regime shifts to sustainability through processes of niche formation: The approach of strategic niche management. Technology Analysis and Strategic Management, 10(2), 175-196.

Kivisaari, S., Lovio, R., \& Väyrynen, E. (2004). Managing experiments for transition. In B. Elzen, F. Geels and K. Green (Eds.), System Innovation and the Transition to Sustainability: Theory, Evidence and Policy (223-250). Cheltenham, UK: Edward Elgar Publishing. 
Kivisaari, S., \& Saranummi, N. (2008). Vuorovaikutteisuus ja systeemiset innovaatiot terveydenhuollossa, In Saari, J. (Ed.). Sosiaaliset innovaatiot ja hyvinvointivaltion muиtos, Sosiaali- ja terveysturvan keskusliitto, Helsinki, 280-300. (In Finnish.)

Kivisaari, S., Saari, E., Lehto, J., Kokkinen, L., \& Saranummi, N. (2009). System innovation in the making: Hybrid actors and the challenge of up-scaling. Second Annual Conference of Health and Care Infrastructure Research and Innovation Centre, 2-3 April 2009, Brighton, UK. Available at:

https://www.vtt.fi/files/projects/Innote/systeminnovationsinthemakingi.pdf (accessed 21 December 2018).

Laslett, P. (1989). A Fresh Map of Life: The Emergence of the Third Age. London: Weidengfeld and Nicolson.

Littig, B., \& Griessler, E. (2005). Social sustainability: A catchword between political pragmatism and social theory. International Journal of Sustainable Development, 8(1-2), $65-79$.

Malanowski, N. (2008). Matching demand and supply: Future technologies for active ageing in Europe. In F. Kohlbacher and C. Herstatt (Eds.). The Silver Market Phenomenon. Business Opportunities in an Era of Demographic Change (41-53). Heidelberg, Germany: Springer.

Markand, J., \& Truffer, B. (2006). Innovation processes in large technical systems: Market liberalisation as a driver for radical change? Research Policy, 35(5), 609-625.

Markand, J., Raven, R., \& Truffer, B. (2012). Sustainability Transitions: An emerging field of research and its prospects. Research Policy, 41(6), 955-967.

Melkas, H., \& Anker, R. (1998). Gender Equality and Occupational Segregation in Nordic Labour Markets. Geneva, Switzerland: ILO.

Neven, L. (2015). By any means? Questioning the link between gerontechnological innovation and older people's wish to live at home. Technological Forecasting \& Social Change, 93, $32-43$.

Oborn, E., \& Barrett S. K. (2016). Digital health and citizen engagement: Changing the face of health service delivery. Health Services Management Research, 29(1-2), 16-20.

Peine, A., Faulkner, A., Jæger, B., \& Moors, E. (2015). Science, technology and the 'grand challenge' of ageing: Understanding the socio-material constitution of later life. Technological Forecasting \& Social Change, 93, 1-9.

Pekkarinen, S. (2011). Innovation of Ageing and Societal Transition: Dynamics of change of the Sociotechnical Regime of Ageing. Acta Universitatis Lappeenrantaensis 423. Lappeenranta University of Technology, Lappeenranta.

Pekkarinen, S., \& Hennala, L. (2016). Robotiikan haasteista. Finnish Journal of eHealth and eWelfare, 8(2-3), 137-138.

Pekkarinen, S., \& Melkas, H. (2017). Digitalisation in Health Care and Elderly Care Services: From potholes to innovation opportunities. International Journal of Information Systems and Social Change 8(1), 24-45.

Pekkarinen, S., \& Melkas, H. (2018; in press). Welfare state transition in the making: Focus on the niche-regime interaction in Finnish elderly care services. Technological Forecasting \& Social Change. https://doi.org/10.1016/j.techfore.2018.09.015 
Pekkarinen, S., Hyypiä, M., Melkas, H., \& Mäkinen, S. (2017). Kokemuksia tablettitietokoneiden käyttöönotosta osana ikääntyneiden asumista. Lahti Science Day. 9 November 2017. (In Finnish.)

Raappana, A., \& Melkas, H. (2009). Teknologian hallittu käyttö vanhuspalveluissa. Opas teknologiapäätösten ja teknologian käytön tueksi. Lappeenranta University of Technology, Lahti School of Innovation. (In Finnish and Swedish.)

Regional Government, Health and Social Services Reform (2018). https://alueuudistus.fi/en/reform-of-regional-administration

Rittel, H. W. J., \& Webber, M. M. (1973). Dilemmas in a General Theory of Planning. Policy Sciences, 4(2), 155-169.

Ródenas, F., \& Garcés, J. (2017). Toward a sustainable welfare and health system in Spain: Experiences with the case-management program. In J. Grin \& J. Broerse (Eds.), Toward Sustainable Transitions in Healthcare Systems (132-152). New York: Routledge.

Schot, J., and Geels, F. (2008). Strategic niche management and sustainable innovation journeys: Theory, findings, research agenda and policy. Technology Analysis and Strategic Management, 20(5), 537-554.

Siegel, C., \& Dorner, T. E. (2017). Information technologies for active and assisted-living: Influences to the quality of life of an ageing society. International Journal of Medical Informatics, 100, 32-45.

Smink, M., Negro, S. O., Niesten, E., \& Hekkert, M. P. (2015). How mismatching institutional logics hinder niche-regime interaction and how boundary spanners intervene, Technological Forecasting and Social Change, 100, 225-237.

Smith, A. (2007). Translating sustainabilities between green niches and socio-technical regimes. Technology Analysis \& Strategic Management, 19(4), 427-450.

Smith, A., Voss, J.-P., \& Grin, J. (2010). Innovation studies and sustainability transitions: The allure of the multi-level perspective and its challenges. Research Policy, 39(4), 435-448.

Toebes, B. C. A. (1999). The Right to Health as a Human Right in International Law. (School of Human Rights Research series; Vol. 1). Antwerp, Belgium: Intersentia.

Truffer, B., \& Coenen, L. (2012). Environmental innovation and sustainability transitions in regional studies. Regional Studies, 46(1), 1-21.

Tuisku, O., Pekkarinen, S., Hennala, L., \& Melkas, H. (2017). Robotit innovaationa hyvinvointipalveluissa. Kysely kentän eri toimijoiden tarpeista, rooleista ja yhteistyöstä. Lappeenrannan teknillinen yliopisto, Tutkimusraportit 70, Lahti. (In Finnish.)

Ulli-Beer, S. (2013). Conceptual grounds of socio-technical transitions and governance. In S. Ulli-Beer (Ed.), Dynamic Governance of Energy Technology Change (19-47). Germany: Springer.

Vavik, T., \& Keitsch, M. (2001). Exploring relationships between universal design and socially sustainable development: Some methodological aspects to the debate on the sciences of sustainability. Sustainable Development, 18(5), 295-305.

Yazan, B. (2015). Three Approaches to Case Study Methods in Education: Yin, Merriam and Stake. Qualitative Report, 20(2), 134-152. Retrieved from https://nsuworks.nova.edu/tqr/vol20/iss2/12

Yin, R. K. (2003). Case Study Research: Design and Methods. Thousand Oaks, CA: Sage Publications. 
Yin, R.K. (2009). Case Study Research: Design and methods. Applied social research methods series. Thousand Oaks, CA: Sage Publications.

Östlund, B. (2017). Digitising Health Care Welfare Technology as a Way to Meet Digital and Demographic Challenges in Sweden. Fourth International Conference on Systems and Informatics (ICSAI 2017).

Östlund, B., Olander, E., Johnsson, O., \& Frennert, S. (2015). STS-inspired design to meet the challenges of modern ageing: Welfare technology as a tool to promote user-driven innovations or another way to keep older users hostage? Technological Forecasting \& Social Change, 93, 82-90. 